Cahiers $d u$ MONDE RUSSE

\section{Cahiers du monde russe}

Russie - Empire russe - Union soviétique et États indépendants

50/2-3 | 2009

L'Europe orientale, 1650-1730. Crises, conflits et renouveau

\title{
The Romanov Empire and NationalismAlexei MILLER
}

, Budapest - New York : Central European University Press, 2008, 242

p.

\section{Malte Rolf}

\section{OpenEdition}

\section{Journals}

Édition électronique

URL : https://journals.openedition.org/monderusse/9781

DOI : 10.4000/monderusse. 9781

ISSN : $1777-5388$

Éditeur

Éditions de l'EHESS

Édition imprimée

Date de publication : 15 septembre 2009

ISBN : 978-2-7132-2260-3

ISSN : $1252-6576$

Référence électronique

Malte Rolf, "The Romanov Empire and NationalismAlexei MILLER », Cahiers du monde russe [En ligne], 50/2-3 | 2009, mis en ligne le 14 janvier 2013, consulté le 03 septembre 2022. URL : http:// journals.openedition.org/monderusse/9781; DOI : https://doi.org/10.4000/monderusse. 9781

Ce document a été généré automatiquement le 3 septembre 2022

Tous droits réservés 


\title{
The Romanov Empire and NationalismAlexei MILLER
}

\author{
, Budapest - New York : Central European University Press, 2008, 242 \\ p.
}

Malte Rolf

\section{Alexei MILLER, The Romanov Empire and Nationalism, Essays in the Methodology of Historical Research, Budapest - New York : Central European University Press, 2008, 242 p.}

1 A new imperial history of the Russian Empire hardly breaks new ground - reprints of older publications show that this paradigm shift is well established by now. However, Alexei Miller's anthology demonstrates that this approach can still pose stimulating questions and provide complex and unexpected answers. The book presents more than a welcomed English collection of Miller's main publications: some of the contributions are new, some have undergone "significant changes," as the author puts it. In sum, the publication is a programmatic road map of the possible paths on which the imperial history of the Romanov Empire can proceed. It is indeed an investigation in the "methodology of historical research."

2 Miller is undoubtedly one of the best known historians who fundamentally changed our view of the Russian Empire within the last ten years. Since the publication in 2000 of his book The Ukrainian Question, Miller has intensively studied the rise of nationalism in Russia during the nineteenth century. He has also been engaged in methodological reflections on how to write the history of a complex, heterogeneous multiethnic and poly-confessional state.

3 The seven essays presented in this volume summarize much of Miller's insights. Miller states his point at the outset: in the introduction, he calls for a close focus on the interaction of actors, for research on the mutuality/interrelatedness of various groups or individuals within changing hierarchies of power of a concrete historical settings. 
Miller calls this the "situational approach" (p. 10-20) and emphasizes that binary models that have shaped imperial history for so long simplify the issue. He points at the multifaceted nature of "the authorities" and the conflicting positions of central and local bureaucrats (p. 3). On the other hand, the "local communities" are characterized by internal frictions and heterogeneity. Traditional national narratives - Miller calls them "regional approaches" - tend to oversee such frictions and continue to produce simplistic models of opposition (state versus society/nations/people).

5 At the same time Miller calls for widening the focus of research by including transimperial flows of concepts, knowledge or people (p. 27-33). The interdependency within the "macrosystem" of continental empires strongly influenced the outcome of identity formation and images of national territories within the Russian Empire, e.g. interimperial and pan-ethnic ideologies had a deep impact on the processes of mental mapping within the Romanov Empire.

Miller backs up these general reflections with empirical material and turns to concrete research questions that are prominent in the field of the history of Empire. His second chapter, "Russification or Russifications?" is undoubtedly a central contribution in this volume. Miller argues that the older notion of one mode of Russification must yield to a consideration of the plurality of forms of Russification. Russifications should be understood as "a whole cluster of various processes and interactions that often differ [...] in their inner logic and nature" (p. 45). The variety of actors, their multitude of intentions and the complexity of interdependencies must therefore be placed at the centre of research. Was complete assimilation indeed the programmatic goal of certain imperial policies? Or did they rather try to foster the introduction of elements of Russianness without touching the basic identity markers of groups or individuals? Here, Miller convincingly calls for a distinction between Russifying efforts that aimed at the active (and partly forceful) Russification of imperial subjects and the unintended processes by which some components of Russian culture and language were adopted by certain groups or individuals. A huge difference existed between projects "to make Russians" and processes of "becoming Russian" (p. 50).

7 In order for us to understand the policies and processes of Russification, the multiple "agents of Russification" and their competing visions of what the Russian Empire should look like must be made key components of historical research. Here, the heterogeneity of such "agents of Russification" will surface; there, the constant interplay between the imperial bureaucracy and public debates will come to light. A wide range of concepts of how, why and when Russification should be pushed forward will appear that undermine the notion of "Russification" as a single monolithic project.

In the following chapters, "Identity and Loyalty in the Language Policy of the Romanov Empire at Her Western Borderlands" and "The Romanov Empire and the Jews," Miller further develops this argument. The chapter on language emphasizes how strongly/ deeply official policies influenced longer identity shaping processes of the imperial subjects, but often had unpredictable effects. For instance, the tsarist ban on the use of "Polish" Latin characters in Ukrainian pushed Ukrainian nationalists to encourage the use of the Cyrillic alphabet in Ukrainian texts. Official regulations could have an (unintended) impact even on the preferences of the regime's counter elites. Thus, the example helps to demonstrate the extent to which decision-making developed in a setting of constant interaction. 
This important insight is, sadly, less visible in the chapter on the Jewish question. While Miller persuasively shows that the Russian policy towards Jewish subjects was strongly influenced by the policies of the neighbouring empires, thus illustrating the transimperial flows of concepts, he does not give a detailed account of the multiple actors on the Jewish side of this entanglement. The picture of a complex interdependency of actors becomes less clear in this case - but even here the heuristic potential of Miller's "situational approach" is obvious.

The last three chapters deal with the rise of Russian nationalism in an imperial context. Miller describes the extent to which such notions as "official," All-Russian, and GreatRussian nationalism were intertwined. In his account, Count Sergei S. Uvarov's "official nationalism" played a crucial role in this development, as it triggered the Russian impetus to nationalize the multinational Empire. In the chapter "The Empire and the Nation in the Imagination of Russian Nationalism" - another major contribution in the volume -, Miller points at the multilayered "mental maps" of Russian nationalism (p. 162). In a Russian nationalist perspective, not all territories, but only a certain core "national territory" of the Empire, were considered as "truly Russian" (although the indivisibility of the Empire as a whole was hardly ever questioned). Russian-national projects mainly aimed at "appropriation" of these territories and often included strongarm "Russification of space" measures (p. 175). Such "imagined geographies" must be taken very seriously, as Miller argues, since they had a great impact on the perceived hierarchy of space. They moulded political concepts/strategies how to deal with/treat/ integrate certain peripheries as much as the ways in which distinct policies were implemented in various territories. Here, Miller also shows how intensively public discourse on what should be considered as "Russian" interacted with the political preferences of the authorities (p. 165). The upper and central layers of the tsarist administration were particularly concerned with the nationalized discourse pushed by the Russian media and public opinion. As Miller puts it, "We can see that part of the higher imperial bureaucracy began to consider the possibility of using nationalism in the empire's interest, while, at the same time, the rank-and-file-bureaucrats and the monarchs themselves invariably treated nationalism with suspicion because of its connection to democratic representations and demand for broader autonomy of public opinion" (p. 212).

11 In the conclusion Miller presents his idea of a methodologically innovative history of Empires: it should be understood, researched and narrated as "the history of interaction of multiple agents, as a field where alternative strategies of identification and alternative nation-building projects competed - often with unpredictable results" (p. 211). Only does a "situational approach" allow historians "to go beyond the traditional narratives", for it facilitates a more complex understanding "of the authorities' policies on the national question, of the mechanism of decision-making and implementation, of the intricate interweaving of interest of the center and of the local elites" (p. 212). One can only agree with such a proposition. Newer research on the Russian Empire does seem to follow the roadmap so well presented in Miller's current compendium of essays. The volume is an important contribution to a further reflection on the methodological assumptions and pitfalls of a new imperial history. 